Editor

Ian Turner, Winchelsea, UK

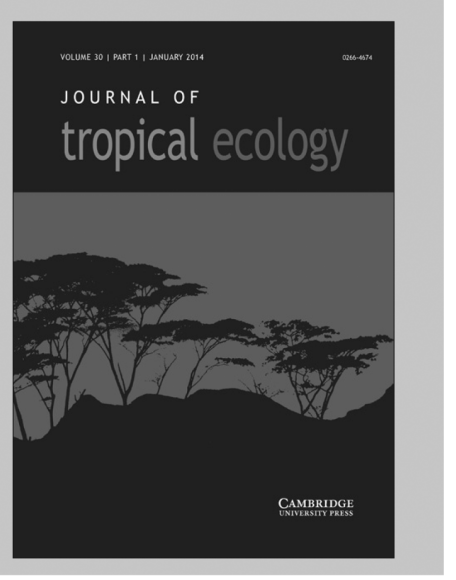

Journal of Tropical Ecology publishes papers in the important and now established field of the ecology of tropical regions, either arising from original research (experimental or descriptive) or forming significant reviews. First published in 1985, Journal of Tropical Ecology has become a major international ecological journal. With clear, stimulating and readable reports of recent research findings, the journal provides a platform for the dissemination of information on all aspects of tropical communities and ecosystems

\title{
Price information
}

is available at: http://journals.cambridge.org/tro

\section{Free email alerts}

Keep up-to-date with new material - sign up at http://journals.cambridge.org/tro-alerts

Journal of Tropical Ecology is available online at: http://journals.cambridge.org/tro

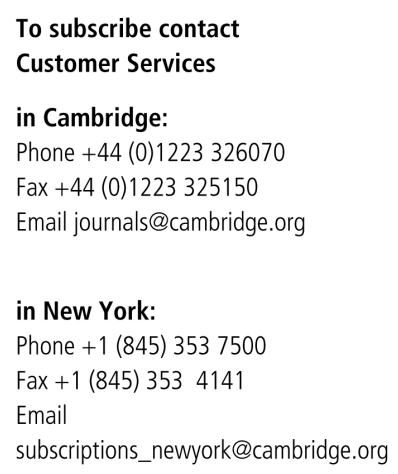
http://journals.cambridge.org/tro 


\section{Parasitology}

Back volumes. Vols. 1-71: Inquiries should be addressed to Wm. Dawson \& Sons Ltd, Cannon House, Folkestone, Kent. Vols. 72 onwards: quotations for parts still in print may be obtained from Cambridge or the American Branch of Cambridge University Press.

Copying. This journal is registered with the Copyright Clearance Center, 222 Rosewood Drive, Danvers, MA 01923, USA. Organizations in the USA who are also registered with C.C.C. may therefore copy material (beyond the limits permitted by sections 107 and 108 of US copyright law) subject to payment to C.C.C. of the per-copy fee of $\$ 16.00$. This consent does not extend to multiple copying for promotional or commercial purposes. Code 0031-1820/2013\$16.00.

Organizations authorized by the Copyright Licensing Agency may also copy material subject to the usual conditions.

ISI Tear Sheet Service. 3501 Market Street, Philadelphia, Pennsylvania 19104, USA, is authorized to supply single copies of separate articles for private use only.

For all other use, permission should be sought from Cambridge or the American Branch of Cambridge University Press.

Claims for missing issues can only be considered if made immediately after receipt of the subsequent issue.

Advertising. Details of advertising in Parasitology may be obtained from the publisher.

Online submission. Authors are encouraged to submit their manuscripts online. Go to http:// mc.manuscriptcentral.com/par/to open an author's account for Parasitology. Manuscript Central is helping to improve the speed of the publication process for the journal.

Front Cover illustration: Eimeria tenella: early-stage immature schizonts at $72 \mathrm{~h}(\mathrm{~A})$ and 2 nd generation large immature and mature schizonts at $84 \mathrm{~h}(\mathrm{~B})$ in the lamina propria; $3 \mathrm{rd}$ generation schizonts in the epithelium of the crypts at $96 \mathrm{~h}$ (E). From Matsubayashi et al. Vol.139(12) pp. 1553-1561.

() Cambridge University Press 2014

The Edinburgh Building, Cambridge CB2 8RU, United Kingdom

32 Avenue of The Americas, New York, NY 10013-2473, USA

477 Williamstown Road, Port Melbourne, VIC 3207, Australia

C/ Orense, 4, Planta 1328020 Madrid, Spain

Lower Ground Floor, Nautica Building, The Water Club, Beach Road,

Granger Bay, 8005 Cape Town, South Africa

Printed in the UK by Bell \& Bain 


\section{PARASITOLOGY}

\section{CONTENTS}

\section{REVIEW ARTICLES}

A brief review of spatial analysis concepts and tools used for mapping, containment and risk modelling of infectious diseases and other illnesses

Graziella Caprarelli and Stephanie Fletcher

The role of chemokines in severe malaria: more than meets the eye

Lisa J. Ioannidis, Catherine Q. Nie and Diana S. Hansen

Dung beetles and fecal helminth transmission: patterns, mechanisms and questions

Elizabeth Nichols and Andrés Gómez

Successful vaccines for naturally occurring protozoal diseases of animals should guide human vaccine research. A review of protozoal vaccines and their designs Milton M. Mcallister

\section{RESEARCH ARTICLES}

Identification of a vir-orthologous immune evasion gene family from primate malaria parasites

Surendra Kumar Prajapati and Om Prakash Singh

Molecular identification of Sarcocystis spp. helped to define the origin of green pythons (Morelia viridis) confiscated in Germany

Gastón Moré, Nikola Pantchev, Daland C. Herrmann, Majda Globokar Vrhovec, Sabine Öfner, Franz J. Conraths and Gereon Schares

Multi-locus sequence typing confirms the clonality of Trichomonas gallinae isolates circulating in European finches Petra Ganas, Barbara Jaskulska, Becki Lawson, Marko Zadravec, Michael Hess and Ivana Bilic
Trichodina heterodentata (Ciliophora) infestation on Prochilodus lineatus larvae: a host-parasite relationship study

Gustavo Moraes Ramos Valladão, Sílvia Umeda Gallani, Santiago Benites De Pádua, Maurício Laterça Martins and Fabiana Pilarski

Molecular subtyping of Blastocystis spp. using a new rDNA marker from the mitochondria-like organelle genome P. Poirier, D. Meloni, C. Nourrisson, I. Wawrzyniak, E. Viscogliosi, V. Livrelli and F. Delbac

Initial studies on mechanism of action and cell death of active $\mathrm{N}$-oxide-containing heterocycles in Trypanosoma cruzi epimastigotes in vitro

Diego Benítez, Gabriela Casanova, Gonzalo Cabrera,

Norbel Galanti, Hugo Cerecetto and Mercedes González

A role for nematocytes in the cellular immune response of the Drosophilid Zaprionus indianus

Balint Z. Kacsoh, Julianna Bozler and Todd A. Schlenke

Conventional PCR for molecular diagnosis of human strongyloidiasis R. B. Sitta, F.M. Malta, J.R. Pinho, P. P. Chieffi, R. C. B. Gryschek and F. M. Paula

OBITUARY

Professor Donald Lee 1931-2013

D.W.T. Crompton and V.R. Southgate 